\title{
腹証について
}

東 京 都

山下 九三夫

長田彼佐子
漢方薬が健保で認められるようになってか ら、患者に投与するためには、腹証の診断が必 要となって来た。腹証を決める腹診法は日本人 の吉益東洞によって開発され、中国で発達した 脈診法之共に、漢方医術の重要な診断の鍵とい える。腹診は、腹筋の緊張と弛紸の状態を観察 するととである。内臓体壁反射としての腹筋の 状態を軸として、その他の腹表に現われる種々 の情報を総合して、全身の病態を評価しょうと するあのである。

腹診法…患者の衣服を充分にあけて、仰臥さ せ、両下肢をのばし、上肢は身体の両脇にお き、力が入らないようにする。先づ肼をみ胸腹 部を軽く掌で数回なでおろし患者の緊張をとき ほぐしながら、腹壁の厚薄、湿潤、乾燥の程 度、腹部の弾力、動悸などを大まかに見極め る。医師は手を暖め、急に押すととなく、食後 か、空腹か、便通はあったか、便秘はどうかを よくきき、慎重に 4 指でおしていくのである。

1）臍について……健康な人の臍は上向きで深 くしまっているが、病人の臍は下向きで浅くし まりが悪い。又臍が自由自在に動くのは無力体 質の陰虚証タイプの人に多く胃腸が弱く、冷え 症のととが多く温補剂、即真武湯、人参湯、四 君子湯が適応する。

2 ) 腹壁の厚薄……腹壁の厚い人は腹部全体に 弾力があり、腹皮だけをつまみあげることはで きない。実証の腹証で大柴胡湯、柴胡加竜骨牲 蚛湯、防風通聖散の証である。腹壁の薄い人は 腹全体に弾力がなくやせていて腹皮だけを筋肉 とはなしてつまむてとが出来る。こういう人は 冷え症で、脈の弱い人に多い。叫君子湯、人参 湯、真武湯の証である。

3 ）腹部胿満……(実満と虚満) 腹部がふく れ、底力があり脈にあ力があって便秘している
のは実証の腹満（実満）であり、底に力がなく 脈の弱いときは虚証の腹満（虚満）である。

4) 胸脇苦満……心下部から、季肋部にかけて の充塞感を自覚し、他覚的にも抵抗圧痛があ る、右側に現われるととが多いが、左右同じに 現われるととああり、左側だけのときもある。 不摂生をすると強くなる。

イ）大柴胡の腹証……胸脇苦満は最も強く、 体格頑丈、便秘傾向にある。

口）小柴胡の腹証……苦満の程度は軽く、肋 骨弓角は狭く便秘は少い。自律神経失調症 候群に有効。

八）四逆散の腹証……小柴胡湯の中間型、 上腹部全体が硬満である。

））柴胡加竜骨牡蚛湯の腹証……苦満の度は 強く、胎上に動悸あり、神経症によい。

ホ）柴胡桂枝湯の腹証……腹直筋が棒状に緊 張している、臍上に冷えを訴えるのは、ス モン病に多い。

へ）柴胡桂枝乾姜湯の腹証……苦満の度は軽 く、臍上に軽い動悸あり、虚弱な、分血症 で、やせた人に多い。

5 ）心下㾂硬……みぞおちが、石のように硬く 抵抗圧痛がある。痁硬の程度の強い場合を、心 下㾂堅という。脚気衝心のときにふれる。半夏 瀉心湯、甘草瀉心湯、三黄鴪心湯を与う。

6 ）腹皮攣急……腹直能が棒状に緊張し、少し 胸脇苦満もある。運動をした人は、腹直筋が固 くなっているので間違えないよう注意。虚証の 腹証である。胃腸系統の症状だけでなく、全身 の精力減退に有勃な桂枝加苟薬湯を与える。

7 ）下腹部膨満と腹皮攀急……㴔を中心にし て、それより下にかけて膨満し、腹直筋を棒状 にふれる。桂枝加苟薬湯、桂枝加苟薬大黄湯を 与う。 
8 ）小腹急結……左の腸骨窩に、急迫的な痛み を感ずる、血滞、水滞の証ともいう。所謂、瘀 血の証である。門脈の整帯、又は腸の瘾着炎症 のあるときに現われる。下腹部の右に圧痛を訴 えるものは索状物をふれるが大黄牡丹皮湯を左 側に圧痛があるときは桃核承気湯を中央部に痛 みのあるときは桂枝获苓丸の証である。

9 ）小腹硬満……下腹部が膨満し堅い抵抗物を ふれる、これも血滞と水滞の証である。

10）小腹拘急……腹直筋が鰧下より䎵骨にかけ て緊張している、腎虚の腹証で八味丸、桂枝加 竜骨牡蚛湯を与える。

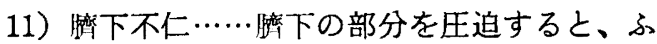
わふわとして陥凹するような状態である。やは り八味丸、桂枝加竜骨牡蚛湯を与う。

12）正中芯……正中線上で臍を中心に上下に 5 〜 $15 \mathrm{~cm}$ の長さで、鉊筆の芯のような硬いもの をふれる、胼上の正中芯は、脾虚の腹証で、真 武湯を与え、臍下の正中芯は留虚の腹証で八味 丸を用いるととが多い。虚証で附子の適応症と いえる。

13）腹部の動悸……心中悸、心下情、脚上悸、 臍下悸がある。神経症や胃腸の弱い人に多い。 補中益気湯、五苓散、半夏厚朴晹、木防已湯、 柴胡桂枝乾姜湯、抑肝散を与える。

14）胃内停水……胃の部分を軽く吒くと、水の 音がする、水毒体質である、助骨弓角が㹨く腹 壁の薄い、胃下垂、胃アトニーのタイプの人に 多い。人参湯、四君子湯、五苓散、半夏厚朴湯 を与える。

15）腸の蠕動不稳……腸がもくもく動くのがわ かる、ガスが多いためである。大建中湯を用い る。

漠方薬を腹証によって投与してみると、約 20 \%に著勃があり、有効は約60\%と思われる。ま た慢性疾患の場合は、約 3 週間は続けて投与.す べきである。

腹診をするにあたって、西洋医学を学んだ我 々は臟器を考えて腹部をみてしまいがちである が、全く素直な気持で手の感覚でおさえてみる ことである。

東洋医学の基礎之臨床、山下九三夫 漢方治療の実際

相見三郎
昭和54年 8 月 19 日 静岡に於て 発表した。

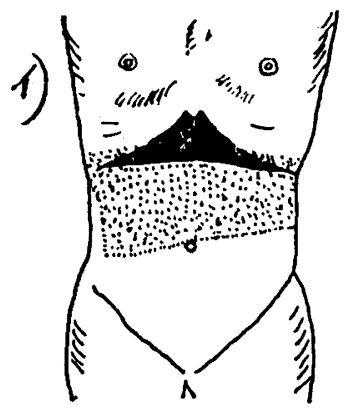

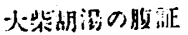

R)

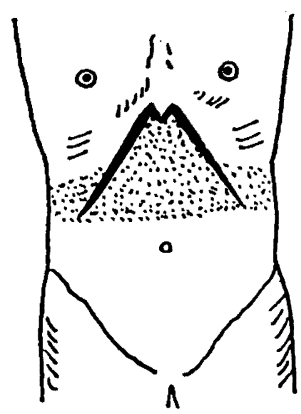

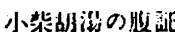

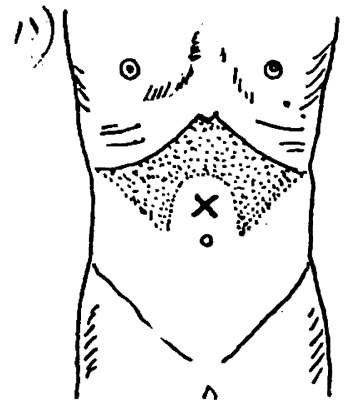

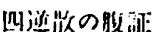

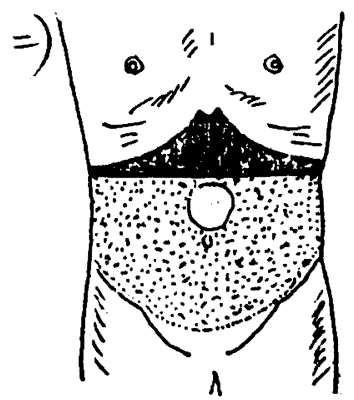

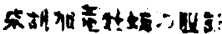




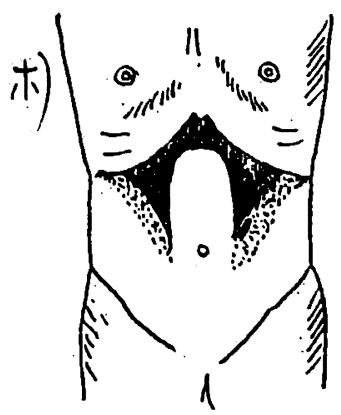

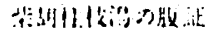

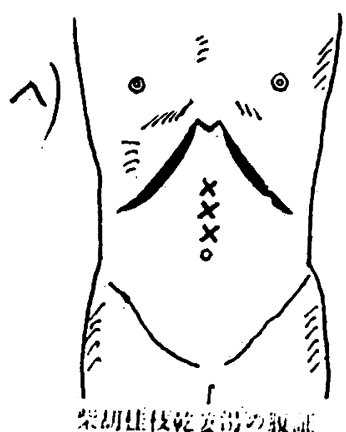

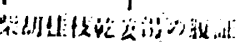
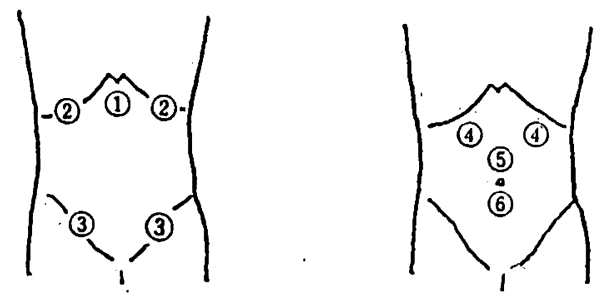

(1) 心 下

(2) 缕胶

(3) 小 脑

(1) 边下

(5) 上

(6) II $\mathrm{F}$

盟圽名称

\section{Abdominal Diagnosis in Kam-po}

In the Western medicine, doctors inspect the patient's abdomen mainly checking swelling or sinking, colour of the skin and dilatation of the superficial vessels, the palpation of the liver edge and swollen sppleen, tumours or defénce musculáire caused by inflammation, for example, appendicitis. However, the abdominal diagnosis in Kampo discovered and widely used by the Japanese in this country is based mainly on the superficial surface signs of the patient's abdomen, and herb medicine are prescribed accordingly. Todo Yoshimasu, the famous Kam-po doctor in Edo era, said that the abdomen is the center of all organs and reveals abnormalities in any kinds of diseases. The sole aim of diagnosis in Kam-po is to determine which herb medicine is best suited for the patient. For example, the sign of "Kyo-kyo-ku-mon"-infra-costal tensionsuggests that 'Saiko' (Bupleurum falcatum) may be used for that patient, etc.

These diagnostic methods which may seem unscientific, are sometimes more rational than the Western diagnostic methods. 